IRA-International Journal of Management \& Social Sciences

ISSN 2455-2267; Vol.08, Issue 01 (July 2017)

Pg. no. 53-61

Institute of Research Advances

http://research-advances.org/index.php/RAJMSS

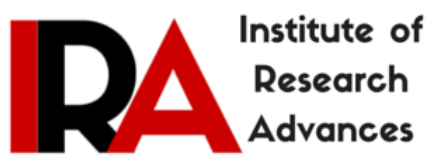

\title{
A Study on Occupational Stress among Railway Employees with Special Reference to Thrissur Railway Station
}

\author{
Neethu Mohan \\ India. \\ Athira Sivaraman \\ Commerce Student, Vimala College, Thrissur, India.
}

Assistant Professor (On Contract), Department of Commerce, St.Joseph's College, Irinjalakuda,

Type of Review: Peer Reviewed.

DOI: http://dx.doi.org/10.21013/jmss.v8.n1.p6

How to cite this paper:
Mohan, N., \& Sivaraman, A. (2017). A Study on Occupational Stress among Railway Employees with
Special Reference to Thrissur Railway Station. IRA-International Journal of Management \& Social Sciences
(ISSN 2455-2267), 8(1), 53-61. doi:http://dx.doi.org/10.21013/jmss.v8.n1.p6

(C) Institute of Research Advances.

\section{(cc) BY-No}

This work is licensed under a Creative Commons Attribution-Non Commercial 4.0 International License subject to proper citation to the publication source of the work.

Disclaimer: The scholarly papers as reviewed and published by the Institute of Research Advances (IRA) are the views and opinions of their respective authors and are not the views or opinions of the IRA. The IRA disclaims of any harm or loss caused due to the published content to any party.

Institute of Research Advances is an institutional publisher member of Publishers Inter Linking Association Inc. (PILA-CrossRef), USA. The institute is an institutional signatory to the Budapest Open Access Initiative, Hungary advocating the open access of scientific and scholarly knowledge. The Institute is a registered content provider under Open Access Initiative Protocol for Metadata Harvesting (OAI-PMH).

The journal is indexed \& included in WorldCat Discovery Service (USA), CrossRef Metadata Search (USA), WorldCat (USA), OCLC (USA), Open J-Gate (India), EZB (Germany) Scilit (Switzerland), Airiti (China), Bielefeld Academic Search Engine (BASE) of Bielefeld University, Germany, PKP Index of Simon Fraser University, Canada. 


\begin{abstract}
Indian railway is one of the income generating industries in India. The industry is a success because of its efficient staff. They are valuable assets of the industry and the key to success. The employees in the Indian railway are experiencing a tremendous amount of pressure at the work place. Increased workloads, overtime, hostile work environment and shift work are just a few causes of stressful working conditions. In such a situation it is necessary to study the occupational stress of railway employees because if not controlled, it can affect the person's family or social life, health, performance etc. hence in the study an attempt has been made to find out the major sources and causes of stress and gather knowledge about the techniques to lower stress. The results of the study show that the employees are facing stressful situations in their work place and they are well aware of the techniques to lower stress.
\end{abstract}

Key words: Indian Railway, Employees, Stressful Working Conditions, Occupational Stress

\title{
INTRODUCTION
}

One of the important functions of the modern management is to get things done through people. It has to bring employees in conduct with the organization in such a way that the objectives of both the groups are achieved. The most significant resource of an organization is often said to be its people. Hence human resources play a crucial role in the development process of modern management. There are many factors which affect the productivity and ability of a person. One among them is stress.

Stress is an all pervading modern phenomenon that takes a heavy toll on human life. Generally, it is a condition of pressure or tension on an individual that affects individual's health and performance at the workplace. Many organizations are facing day-to-day challenges to handle stress in a proper way. Out of all types of stress occupational stress of an employee is very important. Occupational stress is known to affect all professions and category of workers. It is of great concern to management, employees and other stakeholders of the organization. The nature and degree of occupational stress vary across the industry and also in business establishments within an industry. Occupational stress is the result of the interaction of an individual with the work environment and as every job has its own typical environment and every person is different from another. The nature and effect of stress changes from job to job and persons to persons. Occupational stress is the nonspecific response of the body to any demand placed upon it. It is a mental and a physical condition which affects an individual's productivity, effectiveness, personal health and quality of work.

\section{REVIEW OF LITERATURE}

S. Kumar [2016] has made an attempt to study about the 'Occupational stress among BPO workers'. The main objectives of this study were to know the level of occupational stress among BPO workers and to know the difference in occupational stress among male and female BPO workers. The hypotheses were made and a sample of 50 BPO workers was randomly selected from different BPO workers station in Gulbarga City. The study revealed that BPO workers have moderate occupational stress and there is no significant difference in occupational stress among male and female BPO workers.

G. Indhumathi and M. Thirumakkal [2015] have conducted a study to investigate the 'Impact of Stress on Productivity of Employees at the Pothys Boutique, A Textile Showroom.' This was a descriptive study and the main goal was to find the impact of stress on productivity in the organization. Thus the study helped to elucidate descriptive information on the impact of stress on employees at the Pothys Boutique. The sampling used for this study is stratified random sampling. 80 employees of the boutique were the respondents. Questionnaires were distributed to all the employees. The result showed that there were many stress factors which affected their productivity negatively. The important fact was that majority of employees feel that the organization did not care about them. This was a huge reflection of dissatisfaction that undoubtedly lowered productivity. 


\section{OBJECTIVES}

- To find out the major sources and causes of stress.

- Be more aware of the techniques to lower stress.

\section{METHODOLOGY}

The study is based on both primary and secondary data. Primary data have been collected by distributing questionnaires among employees using purposive sampling. The sample size comprised of 80 employees of Thrissur Railway Station. Secondary data were collected from journals, magazines, internet etc. Percentages, pie diagrams and charts were used for analyzing the collected data.

\section{RESULTS AND DISCUSSIONS}

\section{Table 1 - Department Wise Classification}

\begin{tabular}{|c|c|c|}
\hline Department & No. of Respondents & Percentage \\
\hline Traffic and operating & 17 & 21.25 \\
\hline Commercial & 10 & 12.5 \\
\hline Booking office & 7 & 8.75 \\
\hline Signal and Telecommunication & 12 & 15 \\
\hline Reservation & 8 & 10 \\
\hline Electrical and Engineering & 24 & 30 \\
\hline Medical & 2 & 2.5 \\
\hline Total & 80 & 100 \\
\hline
\end{tabular}

Source: Primary Data

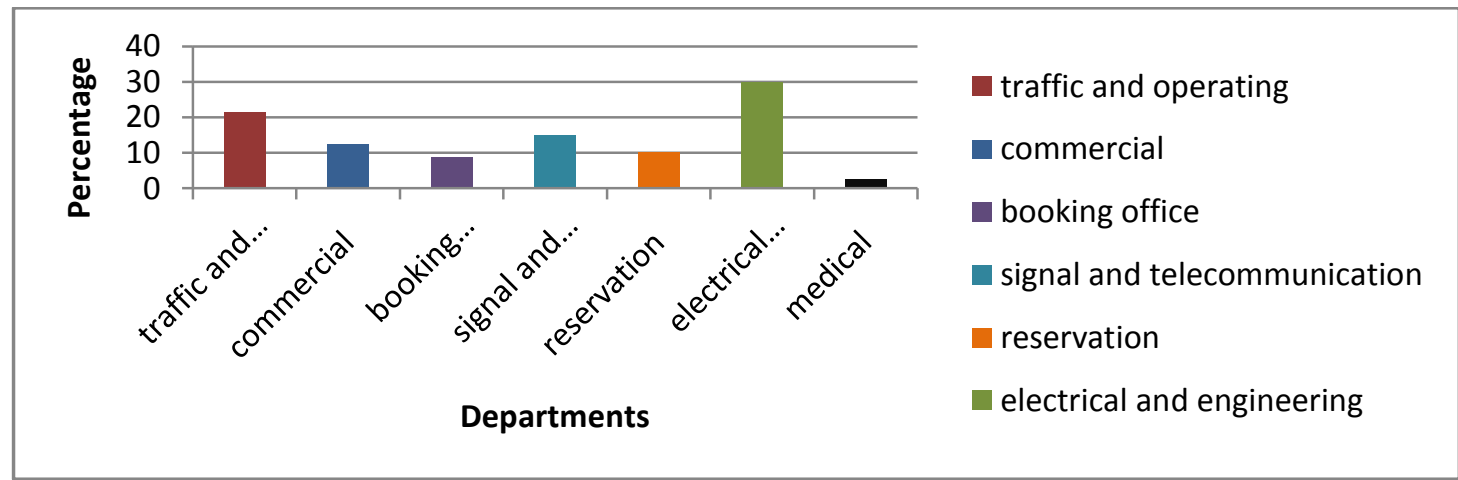

The above table and chart depict that majority of the respondents belong to electric and engineering department followed by other departments.

Table 2- Reasons for Stress of the Respondents

\begin{tabular}{|c|c|c|}
\hline Reasons for Stress & No. of Respondents & Percentage \\
\hline Work environment & 40 & 50 \\
\hline Supervision & 7 & 8.75 \\
\hline Workgroup & 6 & 7.5 \\
\hline
\end{tabular}




\begin{tabular}{|c|c|c|}
\hline Social injustice & 3 & 3.75 \\
\hline Work pressure & 24 & 30 \\
\hline Total & 80 & 100 \\
\hline
\end{tabular}

Source: Primary Data

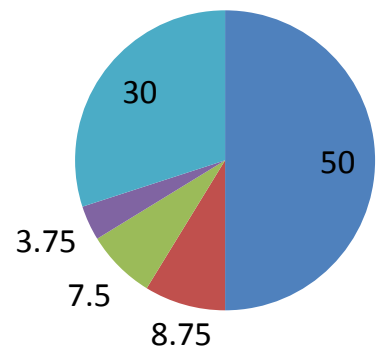

work environment

supervision

work group

social injustice

work pressure

The table and chart reveal that half of the respondents' stress arises because of their work environment. Only a few respondents opined social injustice as the reason for their stress.

Table 3- Factors that Cause Stress in the Workplace

\begin{tabular}{|c|c|c|}
\hline Factors & No of respondents & Percentage \\
\hline Temperature & 14 & 17.5 \\
\hline Lighting & 4 & 5 \\
\hline Gases & 4 & 72.5 \\
\hline Dust or any other factors & 58 & 100 \\
\hline Total & 80 & \\
\hline
\end{tabular}

Source: Primary Data

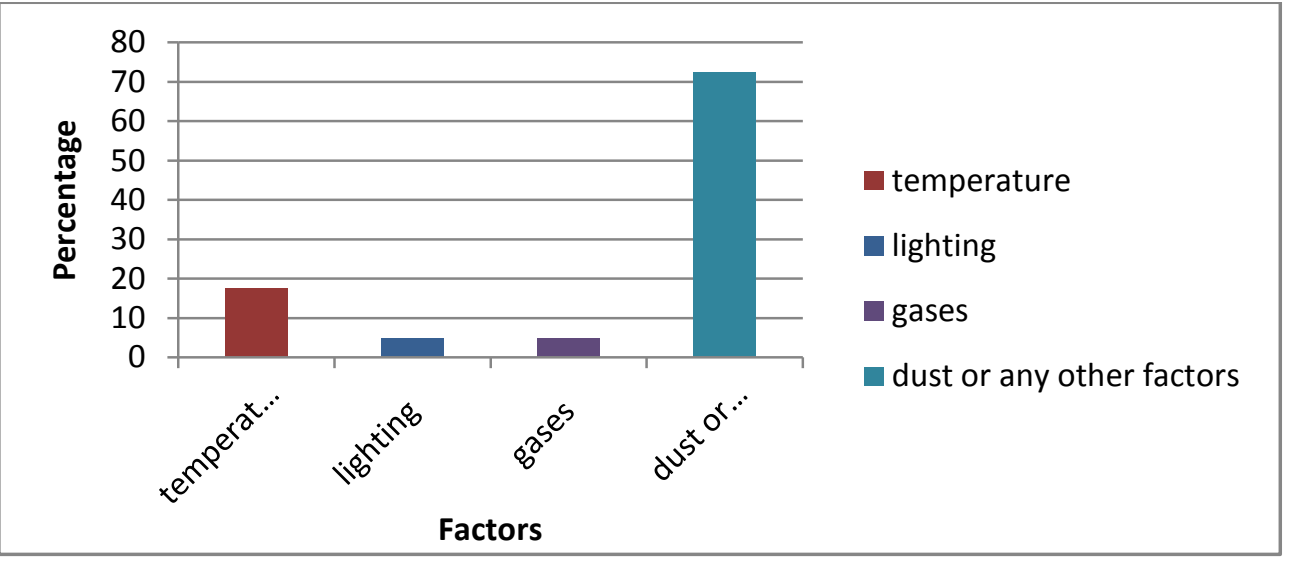


The table and chart infer that majority of the respondents consider dust or other factors as the reason for stress in the work place followed by other factors.

Table 4- Overtime Work of Employees

\begin{tabular}{|c|c|c|}
\hline Responses & No. of Respondents & Percentage \\
\hline Mostly & 34 & 42.5 \\
\hline Rarely & 14 & 17.5 \\
\hline Sometimes & 27 & 33.75 \\
\hline Not at all & 5 & 6.25 \\
\hline Total & 80 & 100 \\
\hline
\end{tabular}

Source: Primary Data

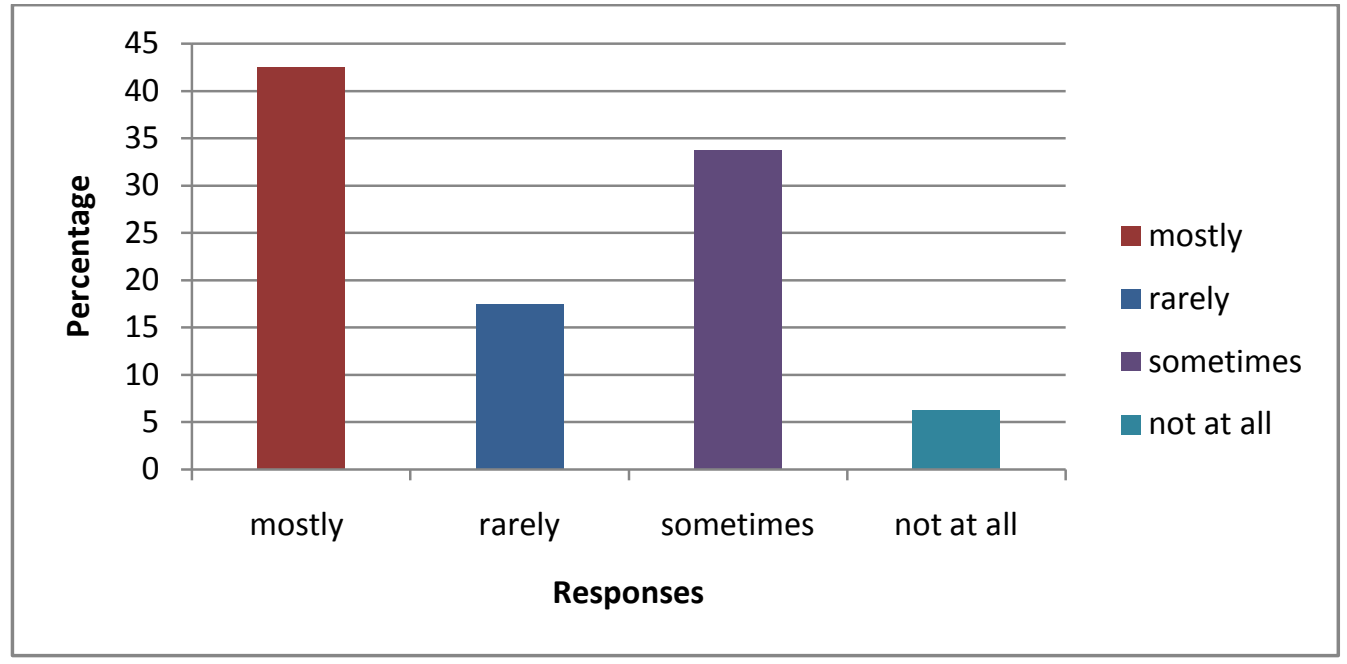

The table and chart show that a major portion of respondents mostly does overtime work.

Table 5- Adverse Effect of Overtime Work on Respondents

\begin{tabular}{|c|c|c|}
\hline Responses & No. of Respondents & Percentage \\
\hline Yes & 62 & 77.5 \\
\hline No & 18 & 22.5 \\
\hline Total & 80 & 100 \\
\hline
\end{tabular}

Source: Primary Data 


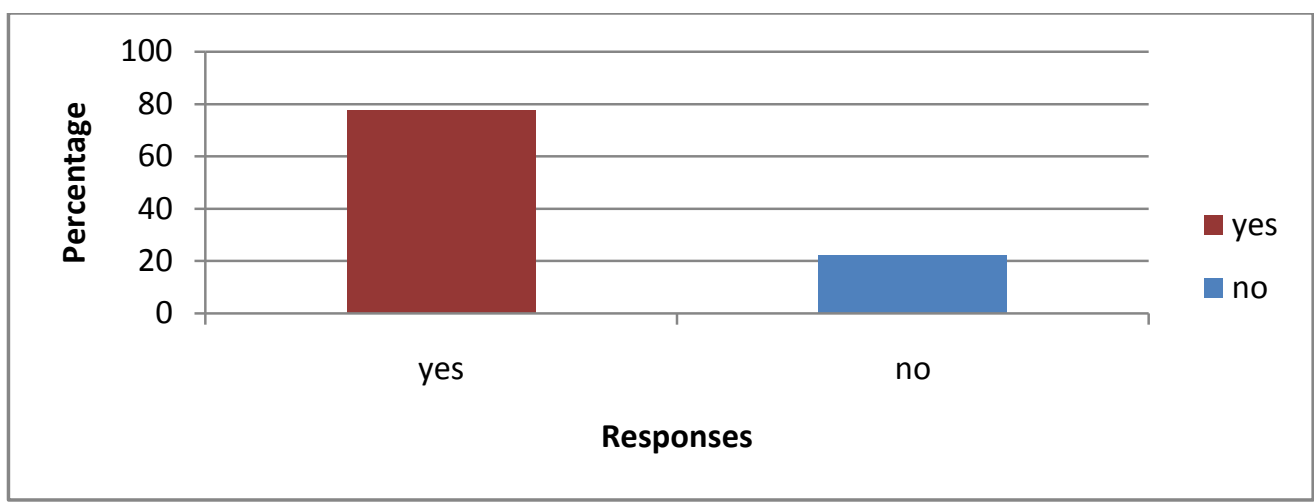

The table and chart depict that overtime work adversely affects the respondents' work.

Table 6 - Symptoms of Stress

\begin{tabular}{|c|c|c|}
\hline Symptoms of Stress & No. of Respondents & Percentage \\
\hline Hypertension & 25 & 31.25 \\
\hline Tiredness & 22 & 27.5 \\
\hline Reduced appetite & 4 & 7.5 \\
\hline Increased smoking or drinking & 6 & 12.5 \\
\hline Frequent headaches & 10 & 16.25 \\
\hline Frequent mood swings & 13 & 100 \\
\hline Total & 80 & \\
\hline
\end{tabular}

Source: Primary Data

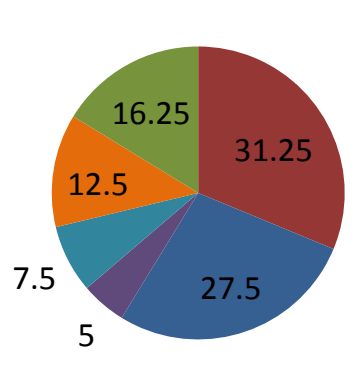

- hypertension

tiredness

reduced appetite

increased smoking or drinking

It can be viewed from the above table and chart that $31.25 \%$ of respondents consider hypertension as the symptom of stress followed by tiredness and frequent mood swings. Only a small percentage has reduced appetite as a symptom of stress. 
Table 7 - Techniques Used to Lower Stress

\begin{tabular}{|c|c|c|}
\hline Techniques & No. of Respondents & Percentage \\
\hline Yoga & 6 & 7.5 \\
\hline Meditation & 6 & 7.5 \\
\hline Breathing exercise & 6.5 \\
\hline Listening to music & 25 & 31.25 \\
\hline Spending quality time with family and \\
friends & 36 & 1.25 \\
\hline Others & 1 & 100 \\
\hline Total & 80 & \\
\hline
\end{tabular}

Source: Primary Data

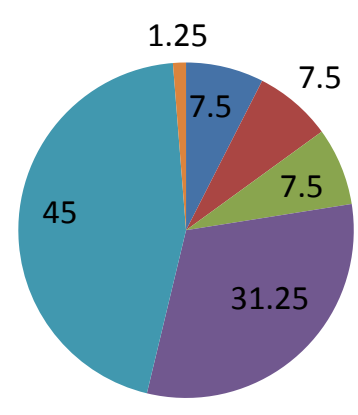

yoga

meditation

breathing exercise

listening to music

The table and chart indicate that $45 \%$ of respondents spend quality time with their family and friends for reducing stress. $31.25 \%$ of them listen to music followed by yoga, meditation, and breathing exercise.

Table 8-Measures to be Taken by the Management to Lower Stress: from Employees' Point of View

\begin{tabular}{|c|c|c|}
\hline Measures & No. of Respondents & Percentage \\
\hline High salary & 21 & 26.25 \\
\hline Recruit supportive staff & 27 & 33.75 \\
\hline Training & 10 & 12.5 \\
\hline Reduce workload & 22 & 27.5 \\
\hline Total & 80 & 100 \\
\hline
\end{tabular}

Source: Primary Data 


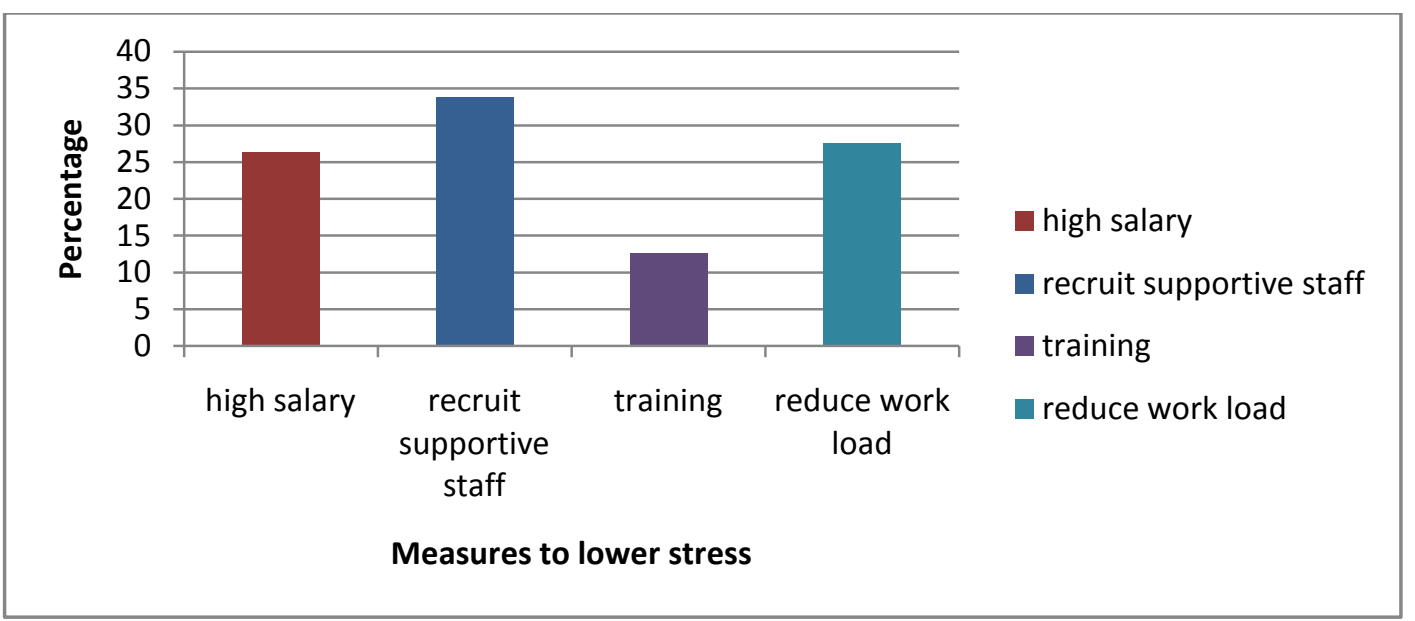

It is clear from the above table and chart that majority of the respondents opined that the management should recruit supportive staff to lower stress followed by other measures.

Table 9 - Stress Management Methods Recommended by the Respondents

\begin{tabular}{|c|c|c|}
\hline Stress Management Methods & No. of Respondents & Percentage \\
\hline Time management & 26 & 32.5 \\
\hline Physiological fitness & 15 & 18.75 \\
\hline Spending quality time with family & 39 & 48.75 \\
\hline Others & - & - \\
\hline Total & 80 & 100 \\
\hline
\end{tabular}

Source: Primary Data

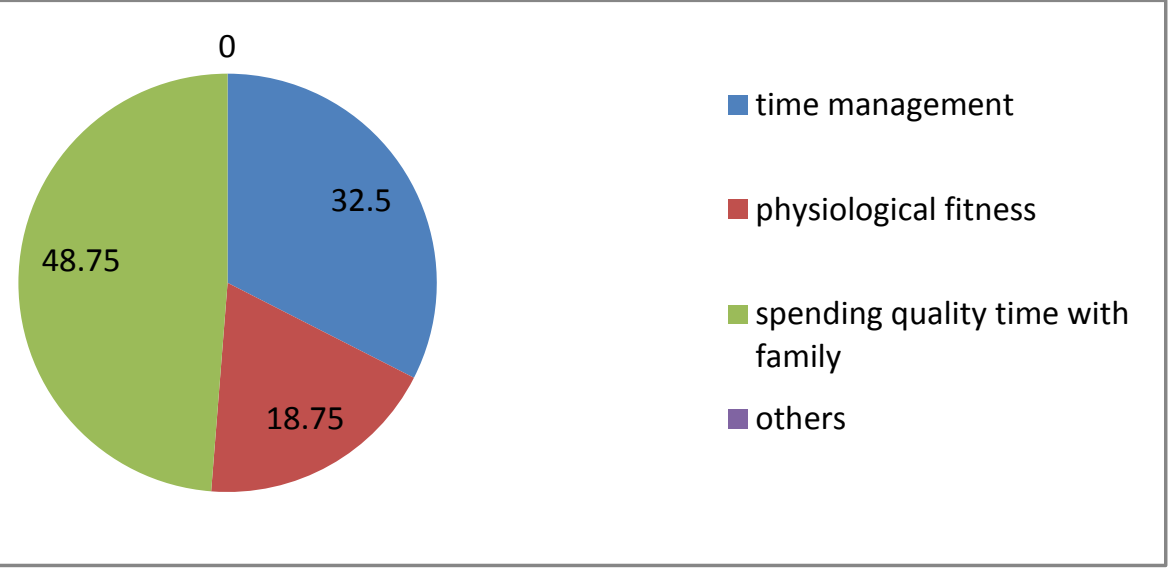

It is evident from the above that $48.75 \%$ respondents suggested spending quality time with family is the best technique to lower stress. $32.5 \%$ of them recommended time management as a good technique to lower stress and the rest of them opted physiological fitness. 


\section{FINDINGS}

1. Majority of the employees responded that they feel stressed mostly because of their work environment.

2. Dust or other factors are the main reason that caused stress in their workplace.

3. Most of the employees consider overtime work causes stress in them and it has an adverse effect on their work.

4. Hypertension and tiredness are considered to be the symptoms of stress experienced by most of the employees.

5. Listening to music and spending quality time with their family are the techniques used by the employees to lower stress.

6. Employees suggested that the management should provide high salary or recruit supportive staff to lower the stress of the employees.

7. Most of the employees recommended that spending quality time with their family and proper time management can help to reduce stress.

\section{CONCLUSION}

Every organization is comprised of people. Maximum productivity can be attained only when the employees are relieved from the stressful situations. The study revealed that most of the employees face stress situation because of the work environment in the organization and overtime work. They consider hypertension and tiredness as the major symptoms of stress. The employees use various techniques like yoga, meditation, spending quality time with family and friends to lower their stress. But still, the management should take reasonable measures to reduce their stress because the employees are the asset of any organization. So they should be taken care of properly because railway is a major source of income generating industry in India.

\section{REFERENCES}

1. Ashok Khurana, Vinu Parida, and Shaveta Grover, T. (2012). "Identifying Reasons of Occupational Stress: A Study of Women Employees". International Journal of Multidisciplinary Management Studies, 2(3), 1632.

2. Gomathi, R. and Deepika, R. (2013). "A Study on Stress Management of Employees at Sakthi Finance Limited, Coimbatore". International Journal of Science and Research, 2(8), 158-161.

3. Indhumathi, G. and Thirumakkal, M. (2015). "A Study on Role of Occupational Stress on Employees Productivity”. International Journal of Management, 6(1), 560-572.

4. Kumar, S. (2016). "A study on occupational stress among BPO workers", The International Journal of Indian Psychology, 4(1), 128-136.

5. Nadeem Malik, (2011). "A Study on Occupational Stress Experienced by Private and Public Bank Employees in Quetta City". African Journal of Business Management, 5(8), 3063-3070.

6. Prasad KDV, Rajesh Vaidya and Anil Kumar, V.(2016)."A Comparative Analysis; Causes of Stress among the Employees and Its Effect on the Performance at the Workplace in Agricultural Research and Information Technology Sectors". AIMA Journal of Management and Research, 10(4/4), 1-23.

7. Prabhu, NRV. And Uma Maheshwari S. (2014), "Occupational Stress- A Study with Reference to Selected Bank Employees in Chennai Region", IOSR Journal of Business and Management, 16(5), 115-125.

8. Sam Renu, R. and Arumugasamy, G. (2013). "Occupational Stress among Pandyan Grama Bank Employees in Virudhunagar District, Tamil Nadu, India". IOSR Journal of Business and Management, 8(4), 53-58.

9. Sivakumar. M. and Dr.Mohammed Siddique, A. (2011). "A Study on Occupational Stress Among IT Professionals Chennai", International Journal of Enterprise Innovation Management Studies, 2(2), 119-124.

10. Xaviour, Selvakumar, A. and Lawrence Immanuel, S. (2015). "Employees Stress Management in Public and Private Sector Banks in Nagapattinam District- An Analysis", Asia Pacific Journal of Research 1(XXVI), 93-102. 